\title{
PAIN DURING THE LABOR ACTIVE PHASE: THE EFFECT OF WALKING
}

\author{
Fabiana Villela Mamede \\ Ana Maria de Almeida ${ }^{1}$ \\ Luiz de Souza \\ Marli Villela Mamede
}

Mamede FV, Almeida AM, Souza L, Mamede MV. Pain during the labor active phase: the effect of walking. Rev Latino-am Enfermagem 2007 novembro-dezembro; 15(6):1157-62.

This study aimed to verify whether the distance walked is correlated with women's pain level throughout the active phase of labor. Methodology: We realized an analytic, quasi-experimental intervention study. Study participants were 80 primiparous parturient women, who were admitted during spontaneous labor, with 37-42 weeks, at the start of the active phase. Data analysis: Spearman's correlation test. Results: the parturient women walked an average distance of 1,624 meters, $63.09 \%$ of the active phase of labor and during an average time of five hours. Pain scores increase along with the advance in cervical dilatation. However, we only found a significant positive correlation when $5 \mathrm{~cm}$ of dilatation had been reached, that is, the more distance the participants walked, the higher the pain scores they reached.

DESCRIPTORS: parturition; pain; walking

\section{EL DOLOR DURANTE LA FASE ACTIVA DEL TRABAJO DE PARTO: EL EFECTO DE DEAMBULACIÓN}

La finalidad de este trabajo fue la de verificar la presencia de correlación entre la distancia deambulada y el nivel del dolor de la parturiente durante toda la fase activa del trabajo de parto. Metodología: estudio analítico de intervención del tipo casi experimental. Participaron del estudio 80 parturientes primíparas, admitidas en trabajo de parto espontáneo, com 37-42 semanas, en el inicio de la fase activa. Análisis de los datos: test de Correlación de Spearman. Resultados: las participantes transcurrieron una distancia media de 1624 metros, $63,09 \%$ de la fase activa del trabajo de parto y en un tiempo promedio de 5 horas. Se verificó que la puntuación de los escores de dolor aumenta a medida que la dilatación cervical avance. Sin embargo, se encontró una correlación positiva significante sólo a los $5 \mathrm{~cm}$. de dilatación, o sea, cuanto mayor los trayectos transcurridos, mayores fueron los escores de dolor alcanzados por las parturientes.

DESCRIPTORES: parto; dolor; caminata

\section{A DOR DURANTE O TRABALHO DE PARTO: O EFEITO DA DEAMBULAÇÃO}

O trabalho teve como objetivo verificar a presença de correlação entre a distância deambulada e os níveis de dor durante a fase ativa do trabalho de parto. Metodologia: estudo analítico de intervenção do tipo quase experimental. Fizeram parte do estudo 80 parturiente primíparas, em trabalho de parto espontâneo, com idade gestacional de 37 a 42 semanas, no início da fase ativa do trabalho de parto. Análise dos dados: Coeficiente de Correlação de Spearman. Resultados: as participantes percorreram uma distância média de 1624metros, 63,09\% da fase ativa do trabalho de parto e em um tempo médio de 5 horas. Quanto aos escores de dor, verificou-se que a pontuação dos mesmos aumentou à medida que a dilatação cervical avançava. Foi encontrada uma correlação positiva apenas aos $5 \mathrm{~cm}$ de dilatação, ou seja, quanto maior os trajetos percorridos maiores foram os escores de dor pontuados pelas parturientes.

DESCRITORES: parto; dor; deambulação

${ }^{1}$ PhD Professor, University of São Paulo at Ribeirão Preto, College of Nursing, WHO Collaborating Center for Nursing Research Development, Brazil, e-mail: famamede@eerp.usp.br; ${ }^{2}$ PhD Professor, University of São Paulo at Ribeirão Preto, Medical School, Brazil; ${ }^{3}$ Full Professor, Universidade de São Paulo at Ribeirão Preto, College of Nursing, WHO Collaborating Center for Nursing Research Development, Brazil 


\section{INTRODUCTION}

Labor pain is a human experience as old as the existence of mankind itself. Today, it still consists of a reality inherent in labor and, even though it can be prevented, many women who get pregnant and give birth still experience it.

Some authors reinforce the idea that the pain women experience during the active phase of labor is a subjective experience, in which different behaviors can be identified, which vary according to culture and time ${ }^{(1-4)}$.

Pain produces a mental answer and reflects in physical actions. The pain women feel during labor is different for each woman and influenced by several factors. The latter include culture, anxiety and fear, previous labor experience, preparation for labor and support provided during this process ${ }^{(5)}$.

From the 30 's to the 60 's, many professionals who assisted parturients believed that pain had an important biological function and that it should not be relieved. On the other hand, the undesired effects of the pharmacological methods available at that time were taken into consideration. In the following decades, especially in the 80 's, a lot of research was carried out, concluding that, even though pain has an important biological function, it needs to be relieved, because the constancy of intense pain is associated to stress and has harmful effects for the mother, the fetus and the newborn ${ }^{(6)}$.

Nowadays, in view of the range of knowledge on the physiological devices that generate pain during labor, several studies have advised on the use of methods to overcome this challenge ${ }^{(7)}$.

Both pharmacological and non pharmacological methods are available today and it is known that the non pharmacological options involve less risk when used in this process. Although the efficiency of some options has not been proved yet, there is trustworthy evidence of the effectiveness of several techniques that may be used during labor, increasing the parturients' comfort.

Walking during the active phase of labor is a technique used to, among other purposes, relieve the pain felt during this period, even though no author explains how this influence occurs ${ }^{(8-11)}$.

In view of these remarks, this study aims to identify, in objective terms, whether the distance the parturient walks during labor has any relation to the level of the painful sensation experienced during this process.

\section{OBJECTIVE}

The objective of this study is to analyze the effects of walking on pain levels during the active phase of labor.

\section{MATERIAL AND METHOD}

Study design

Analytical and quasi-experimental intervention study, in which individuals served as their own controls.

Place of study

The study took place at the Natural Birth Center - NBC of a philanthropic maternity hospital called Amparo Maternal, in the South of São Paulo City - Brazil. The institution has been accredited by the Brazilian Health Ministry and delivers care to pregnant women and parturients from all over the city, with an average of 1100 deliveries a month. Care to natural childbirth is preferentially delivered by obstetric nurses and/or obstetricians.

Study population

The sample consisted of 75 primiparous women who were hospitalized from Mondays to Fridays during the day from June to August 2004 at the NBC, with gestational age between 37 and 42 weeks, with single and topic pregnancy, absence of gestational intercurrence, living fetus in vertex cephalic presentation with good survival conditions. Participants were included in the beginning of the active phase of labor, indicated by: two or more contractions of average intensity every ten minutes, cervical dilation from four to five centimeters and presence of light amniotic fluid evidenced in the amnioscopy. Parturients who presented clinical or obstetric intercurrences during labor were excluded.

The study proposal was approved by the Research Ethics Committee at the University of São Paulo at Ribeirão Preto College of Nursing. The parturients' inclusion in the study respected the ethical principles of research involving human beings and all participants signed a Free and Informed Consent Term. 
Methodological procedures

The following instruments were used for data collection:

Pedometer: a digital counter to measure the distance walked, containing two pairs of electrodes that register average walking speed, number of steps and distance walked in meters. This instrument was connected to a shoe cover used by the parturient.

Numerical Rating Pain Scale: rating scale from 0 to 10 in which the parturient registers the pain perception, considering 0 no pain and 10 the worst pain imaginable.

Data Register Form: comprised by demographic data, cervical dilation records, distance walked, obstetric and neonatal results computed from the parturient's records and the pedometer.

As soon as the parturient had agreed to participate in the study, the Numerical Rating Pain Scale was applied and the walking stimulation was initiated, when the shoe cover with the pedometer were connected to the parturient, which she continued using during the active phase of labor. Then, the parturient was stimulated to start walking. The pain scores as well as the distance walked were measured and registered every hour until the end of the active phase of labor. Data regarding cervical-uterine dilation evaluation and use of medicines were registered according to the labor progress and the procedures followed by the institution professionals.

Study variables

Walking during the active phase of labor; Pain intensity - evaluated through the Numerical Rating Pain Scale

Statistical analysis

Spearman's correlation coefficient was used to evaluate the relation between the parturients' walking and pain score, and Linear Regression to analyze the relation between labor time and the distance walked by the parturients.

\section{RESULTS}

Seventy-five primiparous women in spontaneous labor participated in the study, 23
(30.7\%) of whom were Caucasian and 52 (69.3\%) not Caucasian. Ages varied between 15 and 35 years, with an average of $21.5 \pm 4.7$ years old. Forty-two percent of the participants were adolescents. Among the parturients, a low education level prevailed, as more than the half of them had less than eight years of formal education. Most of them were married or lived in a stable relationship and did not have any paid occupation.

The progress time of the active phase of labor varied from 3 to 14 hours, with an average of $7.66 \pm$ 2.41 hours, as shown in Table 1.

Table 1 - Distribution of the parturients assisted at the Natural Birth Center, according to the interval of progress time in the active phase of labor - TEFA (hours), in July and August 2004. São Paulo - Brazil

\begin{tabular}{|c|c|c|}
\hline TEFA (hours) & Frequency & $\%$ \\
\hline$<6$ & 21 & 28.0 \\
\hline $6 \mid-9$ & 32 & 42.7 \\
\hline $9 \mid-12$ & 18 & 24.0 \\
\hline $12 \mid-14$ & 04 & 5.3 \\
\hline Total & 75 & 100.0 \\
\hline
\end{tabular}

Regarding the interventions the parturients were subject to during labor and delivery, $72.0 \%$ used oxytocic drugs; $84.0 \%$ were submitted to artificial amniotomy; $64.0 \%$ to episiotomy, according to Table 2 .

Table 2 - Distribution of the parturients assisted at the Natural Birth Center, according to the use of oxytocic drugs, kinds of burst of the amniotic bag, kinds of delivery, occurrence of laceration, occurrence of episiotomy, in São Paulo - Brazil in July and August 2004

\begin{tabular}{lcc}
\hline \multicolumn{1}{c}{ Obstetric Results } & Frequency & $\%$ \\
\hline Use of oxytocic drugs & 54 & 72.0 \\
Spontaneous amniotomy & 17 & 22.7 \\
Artificial amniotomy & 63 & 84.0 \\
Cesarean delivery & 1 & 1.3 \\
Natural delivery & 74 & 98.7 \\
Entire perineum & 12 & 16.0 \\
1st degree laceration of the perineum & 12 & 16.0 \\
Episiotomy & 48 & 64.0 \\
Laceration + episiotomy & 2 & 2.7 \\
\hline
\end{tabular}

The weight of the newborns at birth varied from 2,500 to 4,050 grams, with an average of 3,252 \pm 385.7 grams.

Regarding the perinatal results, $96.0 \%$ of the newborns got an Apgar score of seven or more in the first minute, against $98.7 \%$ of the newborns at five minutes. According to the evaluation parameter, this represents good survival conditions. 


\section{WALKING DURING THE ACTIVE PHASE OF LABOR}

The total distance walked by the parturients during the entire active phase of labor varied from 101 to 3,736 meters, with an average of $1,625 \pm 837$ meters.

The distance walked was longer in the first hour of the active phase of labor, with an average of

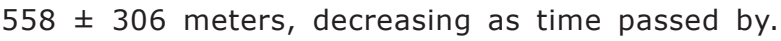
During the three first hours of labor, almost all parturients walked. After this period, three births occurred, which led to a decrease in the sample number. After 9 hours from the beginning of the active phase of labor, $100 \%$ of the parturients who were still in the active phase no longer wanted to walk.

The average calculated from the interruption of walking by the parturients was 5:00 $\pm 1: 45$ hours, corresponding to $63.1 \%$ of the time in the active phase of labor, with an average cervical dilation of $8.4 \pm 1.3 \mathrm{~cm}$.

By associating the distance walked in every hour of the active phase of labor with walking, we observed a significant difference in the first three hours of this phase, which means that parturients who walked a longer distance during the first three hours of the active phase of labor had a reduced duration of labor. However, as of the fourth hour, this association was no longer present.

Proceeding to the estimated reduction in the active phase of labor in the first three hours, we observed that, during the first hour, each 100 meters walked reduced the duration of the active phase of labor by about 22 minutes. In the second hour, the reduction of this phase was 10 minutes for each 100 meters walked. In the third hour, the reduction of this phase was 6 minutes for every 100 meters walked.

By analyzing the parturients' pain scores during the active phase of labor, we observed that all 75 parturients reached the maximum pain score (score 10) was reached until the end of the active phase of labor.

Observing the scores reached by parturients with cervical dilation records of $5,6,7$ and $8 \mathrm{~cm}$, we could see a wide range of scores, according to Table 3 . The variability of pain scores in view of the distance walked at 5, 6, 7 and $8 \mathrm{~cm}$ of dilation showed that, at $5 \mathrm{~cm}$ of dilation, the average distance was 993.7 meters and the parturients' average pain score 6.7. At $6 \mathrm{~cm}$ of dilation, we observed an average distance walked of 1347.3 meters, and an average pain score of 7.4. At 7 and $8 \mathrm{~cm}$ of dilation, average distance walked was 1471.8 and 1441.4 meters, and the average pain score 8.2 and 8.7 , respectively. Finally, it was observed that, as dilation progresses, average pain scores also increase.

Table 3 - Distribution of the parturients assisted at the Natural Birth Center, according to the pain score and distance walked (meters) at 5, 6, 7 and $8 \mathrm{~cm}$ of cervical dilation, in July and August 2004. São Paulo - SP

\begin{tabular}{lccccccccc}
\hline & \multicolumn{3}{c}{$<\mathbf{9 0 0}$ meters } & \multicolumn{3}{c}{$901-1800$ meters } & \multicolumn{3}{c}{ 1801 or more meters } \\
& $\mathbf{N}$ & median & mean & $\mathbf{N}$ & median & mean & $\mathbf{N}$ & median & mean \\
\hline $5 \mathrm{~cm}$ & 16 & 5.0 & 5.9 & 9 & 6.0 & 6.2 & 3 & 8.0 & 8.0 \\
$6 \mathrm{~cm}$ & 11 & 8.0 & 7.6 & 13 & 7.0 & 7.1 & 11 & 8.0 & 7.5 \\
$7 \mathrm{~cm}$ & 09 & 8.0 & 8.2 & 17 & 8.0 & 8.4 & 9 & 8.0 & 8.0 \\
$8 \mathrm{~cm}$ & 08 & 9.5 & 9.0 & 12 & 8.5 & 8.5 & 14 & 9.0 & 8.6 \\
\hline
\end{tabular}

Nevertheless, the pain scores at 5, 6, 7 and $8 \mathrm{~cm}$ of dilation according to the distance walked at the corresponding dilation showed a significant correlation only at $5 \mathrm{~cm}$ of dilation, which means that women who walked furthest at $5 \mathrm{~cm}$ of dilation reached a higher pain score. Table 4 presents Spearman's correlation coefficients between these two variables.

Table 4 - Spearman Correlation coefficients between pain scores according to cervical dilation and distance walked by the parturients assisted at the Natural Birth Center. São Paulo - SP, 2004

\begin{tabular}{cccc}
\hline Cervical dilation $\mathbf{( c m )}$ & $\mathbf{R}$ & $\mathbf{p}$ & Number of parturients \\
\hline 5 & $0.49^{*}$ & 0.01 & 28 \\
6 & 0.01 & 0.93 & 35 \\
7 & 0.03 & 0.87 & 35 \\
8 & -0.09 & 0.63 & 34 \\
\hline
\end{tabular}

* Significant positive correlation at 0.05

\section{DISCUSSION}

The pain/discomfort women feel during labor has two origins, visceral pain and perineal pain. The first results from the first stage of delivery, in which cervical dilation occurs due to the uterine contraction. Normally, in the dilation period, women only feel pain during the contraction. This pain is transmitted by the nervous spinal segment T11-T12 and by the inferior thoracic accessory and superior sympathetic lumbar nerves. These nerves originate in the uterine body and in the cervix. At that moment, the pain is located in the inferior part of the abdomen and irradiates to the lumbar area and thighs, increasing its intensity as uterine contractions increase ${ }^{(5)}$. 
The participants scored the labor pain as having an average progressive intensity that follows the progression of cervical dilation. The influence combined with the advance of cervical dilation and the increased frequency and intensity of the uterine contractions is a logical explanation for the intense pain many woman experience during the end of the first delivery period ${ }^{(12)}$. This fact was observed in this research, especially considering that all women scored the highest pain intensity at 9 and $10 \mathrm{~cm}$ of cervical dilation.

However, such correlations and average amounts do not necessarily reflect the experience of individual women during labor. When the women's pain scores are described individually during labor, a wide variety of high and low score patterns emerges, which seems to be independent both of dilation and of parity (12). Other authors clarify that the pain results in a psychical answer that affects the parturient's physical actions ${ }^{(5,12)}$.

These considerations make sense in view of the research findings, especially when observing the great variability of scores among the parturients until they reached $8 \mathrm{~cm}$ of dilation, as well as among some participants who initiated their labor with high pain scores, which decreased as labor advanced.

Such observations reinforce the fact that the labor pain experience is highly individual, receives various stimulations and is only interpreted through each woman's emotional, motivational, cognitive, social and cultural circumstances ${ }^{(13)}$.

A systematic review made about pain and satisfaction of the women regarding their delivery and birth offers important conclusions when revealing that the amount of support received from the professionals, the quality of their relationship with the professionals (good communication, information, feelings that expressed comfort) and their involvement in decisions making and their personal expectation about their own delivery experience are the most important factors in the definition of women's satisfaction with delivery. The author also concludes that other factors seem to be considered less important, among them the age, social-economical status, ethnic, preparation for the parturition, physical environment of the parturition, deambulation at labor, medical interventions, care continuity and the parturition pain itself ${ }^{(14)}$

The positive correlation found between the distance walked until $5 \mathrm{~cm}$ of dilation and the pain scores of labor (the longer the walking the higher the pain scores) may be related to the fact that our participants were nulliparous. Some authors clarify that the pain standard during labor and delivery seems to be different according to the parity. They add that consistent findings indicate that, during the beginning of the first phase of labor, the nulliparous women experienced a higher average pain than multiparous ones. They also explain that, as labor progresses, these differences are less evident, except during the pelvic phase of labor (deceleration and second phase of labor) in multiparous women ${ }^{(12-14)}$. Physiological differences in delivery progress between nulliparous and multiparous women provide an explanation for these differences observed in pain patterns. Due to the fact that most of the stimulations during the dilation phase (first phase) of labor are attributed to the cervix and the inferior segment of the uterus, a logical explanation is that the characteristics of more flexible structures in women who have already given birth previously may actually transmit less stimulation ${ }^{(12)}$.

As birth work progresses in the pelvic phase (deceleration with descent and fetal expulsion), these same characteristics can lead to an increased perception of pain as a result of the speed and rapidity at which the fetus frequently goes down through the maternal pelvis ${ }^{(12)}$.

In addition, to understand the reasons for correlations between perception of greater pain among the study participants who walked furthest until $5 \mathrm{~cm}$ of cervical dilation, it is believed that the vertical position taken by the parturients in this study favored the greater intensity of uterine contractions, as well as the faster adjustment of the fetal head in the maternal basin, which probably increased pain perceptions.

Another explanation is the fact that women stop walking when they felt too much pain, in other words, women with the highest pain scores walk less because they feel discomfort.

However, the question about the real reasons that made the parturients who walked most at around $5 \mathrm{~cm}$ of dilation register higher pain intensity still remains unanswered. In view of these observations, further studies are suggested to confirm these conclusions.

\section{CONCLUSION}

The results of this study let to the conclusion 
All parturients who participated in this study walked;

The participants walked an average distance of 1,624 meters, representing $63.09 \%$ of the active phase of labor and an average time of 5 hours;

The amount deambulated during the first three hours of the active phase is associated to labor reduction, with a decrease of 22 minutes for every 100 meters walked in the first hour, 10 minutes in the second hour and 6 minutes in the third hour;

Regarding pain scores, it was proved that they increase as cervical dilation advances;

A significant positive correlation was found between walking and the pain score at $5 \mathrm{~cm}$ of dilation, in other words, the longer the distance walked, the higher the parturients' pain scores.

\section{REFERENCES}

1. Helman CG. Cultura, saúde e doença. 2a. ed. Porto Alegre: Artes Médicas; 1994.

2. Gualda DMR. Eu conheço minha natureza: um estudo etnográfico da vivência do parto. [tese]. São Paulo (SP): Escola de Enfermagem/USP; 1993.

3. Lowe NK. The pain and discomfort of labor and birth. J Obstet Gynecol Neonatal Nurs 1996; 25(01):82-92.

4. Gurgel AH, Cruz NL, Fernandes AFC, Silava RM. Fenômeno da dor no trabalho de parto: depoimentos de parturientes. Rev Baiana Enfemagem. 1997; 10(1/2): 95-105.

5. Lowdermilk DL, Perry SE, Bobak IM. O cuidado em enfermagem materna. $5^{a}$ ed. Porto Alegre: Artmed; 2002.

6. Ochiai AM. O banho de chuveiro como medida de alívio da dor no trabalho de parto. [dissertação]. São Paulo (SP): Escola de Enfermagem/USP; 2000.

7. Sabatino H, Dunn PM, Caldeyro-Barcia R. Parto humanizado: formas alternativas. 2a. ed. Campinas: Ed Unicamp; 2000.

8. Mendez-Bauer C, Arroyo J, Garcia Ramos C, Menéndez A, Lavilla M, Izquierdo F, Villa Elízaga I. Effects of standing position on spontaneous uterine contractility and other aspects of labor. J Perinat Med 1975; 3:89-99.

9. Sabatino $H$. Vertical position of the mother during labor. RBM-GO. 1997; 8(2):51-64.

10. Albers $\mathrm{L}$. The relationship of ambulation in labor to operative delivery. J. Nurse Midwifery 1997; 42(1):4-8.

11. Bloom SL, Mcintire DD, Kelly MA, Beimer HL, Burpo RH, Garcia MA et al. Lack of effect of walking on labor and delivery. N Engl J Med 1998; 339(2):76-9.

12. Lowe NK. The nature and management of labor pain: PeerReviewed papers from an evidence-based symposium. Am. J. Obstet. Gynecol. 2002; 186(5): S16-24.

13. Caton D, Coory MP, Frigoletto FD, Hopkins DP, Lieberman $E$, Mayberry $L$ et al. The nature and management of labor pain: executive summary. Am J Obstet Gynecol 2002; 186(5): S1-S15.

14. Hodnett ED, Gates S, Hofmeyr GJ, Sakala C. Continuous support for women during childbirth. (Cochrane Review). In: The Cochrane Library 2003, Issue 3. 